\title{
Do Croatian Companies Recognize Benefits of Integrated Reporting?
}

\author{
Nikolina Dečman * \\ Ana Rep*
}

\begin{abstract}
Timely access to information and business transparency make the foundation for business success. Companies present their financial position and financial performance through the financial statements. As a financial information is not the only relevant factor of business value creation, presentation of non-financial information brings added value to different stakeholders. For the purpose of more transparent business operations and international comparability of the presented data, it is especially important that reports are compiled according to internationally accepted rules. The paper has sought to investigate whether Croatian companies recognize benefits of integrated reporting. The aim of the paper was to identify whether and to what extent largest companies in Croatia present the information regarding their intellectual capital, principle customers, business partners, environmental considerations, future plans, investments, market conditions, and further expectations of business development. Based on the research results, suggestions for improvement of the non-financial reporting in Croatia have been given.
\end{abstract}

Keywords: integrated reporting; sustainability; benefits; stakeholders; Croatian companies

JEL Classification: M41

\section{Introduction}

Many users are interested in companies' performance. Some want to evaluate the reliability and long-term relationships with business partners, some want to explore long-term success of business, whether the company comply with the highest ethical standards, does the company accomplish set goals and similar issues. Until recently, the emphasis in reporting was exclusively on financial information. However, today's

\footnotetext{
* Nikolina Dečman and Ana Rep are at University of Zagreb, Faculty of Economics and Business, Zagreb, Croatia.
} 
attention is increasingly attributed to intangible values that are often not recorded in the financial statements. Therefore, the concept of integrated reporting develops very rapidly. The importance of this reporting concept is evidenced by the fact that "integrated reporting may become the twenty-first century revolution in corporate reporting" (Kassai and Carvalho, 2016).

A company cannot work without employees, technology, and financial capital. Society, environment, and business relationships also make a big impact on business value creation. Thus, business value creation is the result of the impact of financial, human, intellectual, manufactured, natural, and society capital. It is difficult to measure their impact to the value creation in financial terms, but that is not a reason not to present it. The company should present the impact of mentioned factors through non-financial information. By doing so companies present their business to the interested parties in a transparent way, not only by presenting the historical data, but also presenting the present work and future plans of their business. Non-financial information can be presented either in the notes to financial statements or in the annual report, but the company can also prepare a separate report presenting all impacts on business value creation. Although most companies are reluctant to create additional reports, it has been noticed that this is a good practice in many countries in which companies have already implemented the integrated reporting. The main goal of this paper is to explore whether Croatian companies recognize benefits of integrated reporting and what information they publish. The research methodology has included a secondary research of the active projects conducted by relevant organizations and a primary research of the non-financial disclosures presented by the largest companies in Croatia.

\section{Regulatory Framework for Implementing Integrated Reporting into Practice}

There are many definitions of integrated reporting. International Integrated Reporting Council (IIRC) defines an integrated report as "a concise communication about how an organization's strategy, governance, performance and prospects, in the context of its external environment, lead to the creation of value in the short, medium and long term.” "Integrated reporting is a combination of financial and non-financial information intended primarily for external stakeholders, and it is also an effective management control tool, as it promotes integrated thinking, strengthens the company's reputation and overall success" (Vitezić and Petrlić, 2018). The importance of this reporting concept is evidenced by the fact that the European Commission recognizes the importance of disclosing non-financial information too. Directive 2014/95/EU defines that "large public-interest entities exceeding on their balance sheet dates the criterion of the average number of 500 employees during the financial year shall include in the management report a non-financial statement from 2018 
onwards. It should contain information to the extent necessary for an understanding of the undertaking's development, performance, position and impact of its activity, relating to, as a minimum, environmental, social and employee matters, respect for human rights, anti-corruption and bribery matters" (European Parliament and Council, 2014). Until recently, this kind of reporting was not compulsory although companies have voluntarily reported on social responsibility and environmental issues. Today, for all member states of the European Union as well as the Republic of Croatia, there is an obligation to include the non-financial report in the management report. Directive gives possibility to exempt companies from the obligation to prepare the non-financial statement when a separate report corresponding to the same financial year and covering the same content is provided. However, no exact guide or rule that strictly defines the content of this report is prescribed. Directive 2014/95/EU suggests users to use national frameworks, Union-based frameworks or international frameworks when preparing non-financial report. ${ }^{1}$ In order to facilitate disclosure of non-financial information, the European Commission (2017) has undertaken to draw up non-binding guidelines for the preparation of the non-financial report, taking into account current best practices, international trends and the results of related Union initiatives, and in July 2017 the Commission published Guidelines on non-financial reporting - Methodology for reporting non-financial information (2017/C215/01). Table 1 presents the key principles of compiling the non-financial report as well as its content elements. It is visible that one of the most important principle is disclosure of material and comprehensive, but concise and forward-looking information. As far as the content of the non-financial report, Guidelines on non-financial reporting do not depart from the Directive 2014/95/EU. Their most valuable output is an overview of key performance indicators relating to aspects such as environmental and climate-related matters, social and employee matters, respect for human rights, anti-corruption and bribery matters as well as other specific supply chain matters.

Table 1: Methodology for reporting non-financial information according to EC Guidelines on non-financial reporting

\begin{tabular}{|l|l|}
\hline \multicolumn{1}{|c|}{ KEY PRINCIPLES } & \multicolumn{1}{c|}{ CONTENT ELEMENTS } \\
\hline Disclose material information & Business Model \\
\hline Fair, balanced and understandable & Policies and due diligence \\
\hline Comprehensive but concise & Outcome \\
\hline Strategic and forward-looking & Principal risks and their management \\
\hline Stakeholder orientated & Key Performance Indicators \\
\hline Consistent and coherent & Thematic aspects \\
\hline
\end{tabular}

Source: European Commission (2017)

In addition to the guidelines issued by the European Commission, a number of internationally recognized guides that can be helpful in creating and presenting in- 
tegrated report exists. Table 2 shows comparative view of reporting principles and content elements of integrated report according to two most significant international frameworks for integrated reporting: International Integrated Reporting Framework and Global Reporting Initiative - Sustainability Reporting Standards. The International Integrated Reporting Council has been developing the International Integrated Reporting Framework, which is principle-based framework that identifies information to be included in the integrated report for primarily private profit oriented companies. Global Reporting Initiative (GRI) is an independent international organization founded in 1997 in Boston that promotes sustainability reporting. The GRI Sustainability Reporting Standards are the first and most widely adopted global standards for sustainability reporting (for more details see Global Reporting Initiative, 2018).

Table 2: Comparative analysis of reporting principles and content elements of integrated report

\begin{tabular}{|c|c|c|}
\hline \multicolumn{3}{|c|}{ International Integrated Reporting Framework (IIRC 2013) } \\
\hline \multirow{7}{*}{$\begin{array}{l}\text { Guiding } \\
\text { Principles }\end{array}$} & $\begin{array}{l}\text { Strategic focus and } \\
\text { future orientation }\end{array}$ & $\begin{array}{l}\text { Provide insight into the organization's strategy, and how it relates to the organization's } \\
\text { ability to create value in the short, medium and long term, and to its use of and effects } \\
\text { on the capitals. }\end{array}$ \\
\hline & $\begin{array}{l}\text { Connectivity of } \\
\text { information }\end{array}$ & $\begin{array}{l}\text { Show a holistic picture of the combination, interrelatedness and dependencies between } \\
\text { the factors that affect the organization's ability to create value over time. }\end{array}$ \\
\hline & $\begin{array}{l}\text { Stakeholder } \\
\text { relationships }\end{array}$ & $\begin{array}{l}\text { Provide insight into the nature and quality of the organization's relationships with its key } \\
\text { stakeholders, including how and to what extent the organization understands, takes into } \\
\text { account and responds to their legitimate needs and interests. }\end{array}$ \\
\hline & Materiality & $\begin{array}{l}\text { Disclose information about matters that substantively affect the organization's ability to } \\
\text { create value over the short, medium and long term. }\end{array}$ \\
\hline & Conciseness & An integrated report should be concise. \\
\hline & $\begin{array}{l}\text { Reliability and } \\
\text { completeness }\end{array}$ & $\begin{array}{l}\text { Include all material matters, both positive and negative, in a balanced way and without } \\
\text { material error. }\end{array}$ \\
\hline & $\begin{array}{l}\text { Consistency over } \\
\text { time }\end{array}$ & $\begin{array}{l}\text { The information in an integrated report should be presented: (a) on a basis that is consist- } \\
\text { ent over time; and (b) in a way that enables comparison with other organizations to the } \\
\text { extent it is material to the organization's own ability to create value over time. }\end{array}$ \\
\hline \multirow{8}{*}{$\begin{array}{l}\text { Content } \\
\text { Elements }\end{array}$} & $\begin{array}{l}\text { Organizational } \\
\text { overview } \\
\text { and external } \\
\text { environment }\end{array}$ & What does the organization do and what are the circumstances under which it operates? \\
\hline & Governance & $\begin{array}{l}\text { How does the organization's governance structure support its ability to create value in the } \\
\text { short, medium and long term? }\end{array}$ \\
\hline & Business model & What is the organization's business model? \\
\hline & $\begin{array}{l}\text { Risks and } \\
\text { opportunities }\end{array}$ & $\begin{array}{l}\text { What are the specific risks and opportunities that affect the organization's ability to create } \\
\text { value over the short, medium and long term and how is the organization dealing with } \\
\text { them? }\end{array}$ \\
\hline & $\begin{array}{l}\text { Strategy and } \\
\text { resource allocation }\end{array}$ & Where does the organization want to go and how does it intend to get there? \\
\hline & Performance & $\begin{array}{l}\text { To what extent has the organization achieved its strategic objectives for the period and } \\
\text { what are its outcomes in terms of effects on the capitals? }\end{array}$ \\
\hline & Outlook & $\begin{array}{l}\text { What challenges and uncertainties is the organization likely to encounter in pursuing } \\
\text { its strategy, and what are the potential implications for its business model and future } \\
\text { performance? }\end{array}$ \\
\hline & $\begin{array}{l}\text { Basis of } \\
\text { presentation }\end{array}$ & $\begin{array}{l}\text { How does the organization determine what matters to include in the integrated report and } \\
\text { how are such matters quantified or evaluated? }\end{array}$ \\
\hline
\end{tabular}


Table 2. Continued

\begin{tabular}{|c|c|c|}
\hline \multicolumn{3}{|c|}{ GRI Sustainability Reporting Standard - GRI 101} \\
\hline \multirow{4}{*}{$\begin{array}{l}\text { Reporting } \\
\text { Principles } \\
\text { for } \\
\text { defining } \\
\text { report } \\
\text { content }\end{array}$} & $\begin{array}{l}\text { Stakeholder } \\
\text { Inclusiveness }\end{array}$ & $\begin{array}{l}\text { The reporting organization shall identify its stakeholders, and explain how it has respond- } \\
\text { ed to their reasonable expectations and interests. }\end{array}$ \\
\hline & $\begin{array}{l}\text { Sustainability } \\
\text { Context }\end{array}$ & $\begin{array}{l}\text { The report shall present the reporting organization's performance in the wider context of } \\
\text { sustainability. }\end{array}$ \\
\hline & Materiality & $\begin{array}{l}\text { The report shall cover topics that reflect the reporting organization's significant economic, } \\
\text { environmental, and social impacts or influence the assessments and decisions of stake- } \\
\text { holders. }\end{array}$ \\
\hline & Completeness & $\begin{array}{l}\text { The report shall include coverage of material topics and their Boundaries, sufficient to re- } \\
\text { flect significant economic, environmental, and social impacts, and to enable stakeholders } \\
\text { to assess the reporting organization's performance in the reporting period. }\end{array}$ \\
\hline \multirow{6}{*}{$\begin{array}{l}\text { Reporting } \\
\text { Principles } \\
\text { for } \\
\text { defining } \\
\text { report } \\
\text { quality }\end{array}$} & Accuracy & $\begin{array}{l}\text { The reported information shall be sufficiently accurate and detailed for stakeholders to } \\
\text { assess the reporting organization's performance. }\end{array}$ \\
\hline & Balance & $\begin{array}{l}\text { The reported information shall reflect positive and negative aspects of the reporting or- } \\
\text { ganization's performance to enable a reasoned assessment of overall performance. }\end{array}$ \\
\hline & Clarity & $\begin{array}{l}\text { The reporting organization shall make information available in a manner that is under- } \\
\text { standable and accessible to stakeholders using that information }\end{array}$ \\
\hline & Comparability & $\begin{array}{l}\text { The reporting organization shall select, compile, and report information consistently. The } \\
\text { reported information shall be presented in a manner that enables stakeholders to analyse } \\
\text { changes in the organization's performance over time, and that could support analysis rel- } \\
\text { ative to other organizations. }\end{array}$ \\
\hline & Reliability & $\begin{array}{l}\text { The reporting organization shall gather, record, compile, analyze, and report information } \\
\text { and processes used in the preparation of the report in a way that they can be subject to } \\
\text { examination, and that establishes the quality and materiality of the information. }\end{array}$ \\
\hline & Timeliness & $\begin{array}{l}\text { The reporting organization shall report on a regular schedule so that information is avail- } \\
\text { able in time for stakeholders to make informed decisions. }\end{array}$ \\
\hline
\end{tabular}

Source: According to IIRC (2013) and Global Sustainability Standards Board (2016)

\section{Exploring Benefits of Integrated Reporting for Companies}

Business reporting enables greater visibility for everyone, those who work within the company and especially those who are not familiar with daily operations of company, their potential investors, creditors, and other stakeholders. While reporting on financial position and business performance through financial statements is a common rule, companies need to focus increasingly on disclosing information of non-financial nature in order to provide a complete picture how companies truly create long-term value. IIRC's Framework sets several objectives for integrated reporting (Black Sun PLC and Association of International Certified Professional Accountants, 2018): (1) improve the quality of information available to providers of financial capital to enable a more efficient and productive allocation of capital; (2) provide a more cohesive and efficient approach to corporate reporting that draws on different reporting strands and communicates the full range of factors that materially affect the ability of an organisation to create value over time; (3) enhance accountability and stewardship for the broad base of capitals (financial, manufactured, intellectual, human, social and relationship, and natural) and promote understanding of their interdependencies; (4) support integrated thinking, decision-making and actions that focus on the creation of value over the short, medium and long-term. 
Many studies confirm that integrated reporting can contribute to long-term success. According to PricewaterhouseCoopers (2015) survey, "almost 75 \% CEOs say that measuring and reporting the total impact of their company's activities across social, environmental, fiscal and economic dimensions contributes to the long-term success of their organizations." It is interesting to explore the opinions of those who have already implemented the concept of integrated reporting in practice where the results show that „79 \% of respondents are already finding that business decision making has improved; $68 \%$ report better understanding of risks and opportunities; and $78 \%$ see better collaborative thinking by the board about goals and targets" (Black Sun and IIRC, 2014). According to KPMG (2017) Survey of Corporate Responsibility Reporting 2017, ten countries with the highest rates of corporate responsibility information in annual financial reports are: India (98\%), Malaysia (93\%), UK ( $92 \%$ ), South Africa (91 \%), Taiwan ( $88 \%$ ), Denmark (86\%), France (83\%), US $(81 \%)$, Norway $(81 \%)$ and Sweden $(80 \%)$. Integrated reporting contributes to the value of the company in a direct and indirect way. Direct value can be seen in cost reduction and revenue growth while indirect value can be seen in better risk management as well as brand enhancement, improved market access or licence to operate, improved security, and quality of supply (for more information see PwC, 2015).

The Croatian Institute for Corporate Social Responsibility recognizes the advantages of integrated reporting from the perspective of internal users and other external stakeholders. Potential advantages of integrated reporting for internal users are better understanding of enterprise strategy and social, environmental as well as economic impacts, creating new business opportunities. Risk assessment is improved, resulting in lower costs and more efficient business operations. There is a better understanding of resource constraints resulting in innovations of new goods and services, and increased levels of internal and external awareness and reputation, resulting in greater loyalty and lower staff recruitment and retention costs. On the other hand, greater transparency is ensured which implies stronger stakeholder confidence and reputation. Better understanding of the risks and business challenges assists companies in achieving competitive position on the market characterized by an enhanced brand value and a stronger relationship with consumers (for more details see Institute for Corporate Social Responsibility, 2018). Accounting majors also recognize advantages of integrated reporting. According to James (2015) future accountants perceived that the most important benefits arising from sustainability (integrated) reporting were enhanced reputation, increased profit and enhanced customer loyalty. On the other hand, they anticipated some concerns about the accuracy and completeness of the reported information, short-term reporting costs, and competition and disclosure of proprietary information. Several studies on non-financial reporting have been conducted in the Republic of Croatia. Galant and Černe (2017) analysed current state of non-financial reporting in Croatia, as well as the financial characteristics of companies that decide to disclose non-financial reports. Research results indicate that larg- 
er, more profitable and successful companies are more probable to disclose non-financial reports. In addition, further development of corporate social accounting is required, as well as promotion of non-financial reporting benefits (Galant and Černe, 2017). There is an opinion that the benefits of integrated reporting are reserved for large entities. The question is whether there are advantages of integrated reporting for SMEs too. The research conducted by James (2012) shows that integrated reporting may enable small and medium enterprises to obtain funding for expansion projects, gain new investors or even provide opportunities for acquisition by another company. Dečman (2016) discusses whether Croatian SMEs report on the non-accounting information in their annual reports and examines the extent to which they consider the non-accounting information is used in the management of a company. According to the research results, Croatian small and medium-sized enterprises consider non-accounting information useful and valuable for the purpose of management (Dečman, 2016). However, accounting information is used to a greater extent. IFAC supports the standpoint that smaller entities can also achieve significant benefits from integrated reporting. Attolini and Pozzoli (2014) believe that SMEs typically interact and affect many entities. Therefore, they see integrated reporting as the main tool to demonstrate that SMEs take into consideration and actively communicate comprehensive information with the community. Therefore, there are advantages from integrated reporting for all companies regardless of their size. The only rule that should be respected is that the costs do not exceed the benefits of integrated reporting. In order to explore current state of integrated reporting in Croatia, authors have conducted analysis of available non-financial information in annual reports and notes to the financial statements of the largest Croatian companies.

\section{Empirical Research on Integrated Reporting - The Case of Croatia}

An empirical research on integrated reporting has been conducted on a sample of Croatian companies using a list of the top twenty companies registered in the Republic of Croatia by total revenue in financial year 2016. The research was directed to the non-financial information presented in notes to the financial statements and annual report. The reports were downloaded from the Financial Agency, the Croatian agency to which Croatian companies have to submit financial statements. All companies taken into research sample are large companies. According to the Croatian Accounting Act, large entities need to prepare and submit the statement of financial position, income statement, statement of changes in equity, cash flow statement and notes to the financial statements. In addition to the principal financial statements, they have to prepare and publicly announce the annual report. There is no formal obligation for Croatian companies to prepare and announce the integrated report, but large companies usually disclose some non-financial information in the annual re- 
port or in notes to the financial statements. This is the main reason why authors have focused their analysis on non-financial information. The following information was analysed: intellectual capital, principle customers, business partners, environmental considerations, future plans, investments, market conditions, and further expectations of business development. All these positions can be split into the financial, manufactured, intellectual, human, social and relationship, and natural capital identified by integrated reporting.

The primary research has been focused on the study of non-financial information that has been marked as dummy variable. If the company has disclosed the requested information, that position was marked with 1 , otherwise it was marked with 0 . Table 3 presents results of the conducted research. It can be seen that two out of twenty companies taken into the research sample disclosed all the investigated information. Only one company creates the annual report according to the Global Reporting Initiative guidelines. Most companies have presented more than $50 \%$ of investigated information, but it can be said that most information was general since companies use templates from previous years when preparing their reports. Only 30 $\%$ of analysed companies have disclosed information about principle customers. All companies have disclosed the financial information about account receivables, but non-financial information about principle customers has not been disclosed by $70 \%$ of the companies. Although the results show that $95 \%$ of companies have disclosed the information about future plans, it mainly includes statements that the company will continue to keep the current market position and take actions to comply with their mission and vision. Company's plans should refer to the specific actions which are planned to be undertaken in future periods in order to achieve the strategic goals set by the company. During the research, it was noted that all companies have disclosed the information about the risks the company faces with, but most companies have disclosed similar risks even though they belong to various industries. Nonetheless, only three companies have presented their specific opportunities that increase the organizations' ability to create value over time and only two of them presented their business model. According to the International Integrated Reporting Framework (IIRC, 2013) the core of an organization is its business model, which draws on various capitals as inputs and, through its business activities, converts them to outputs (products, services, by-products and waste). For investors, it is very important to be familiar with company's business activities and their impact to the financial capital over short, medium and long-term. 
Table 3: Disclosure analysis of non-financial information in Croatian largest companies

\begin{tabular}{|c|c|c|c|c|c|c|c|c|c|c|}
\hline 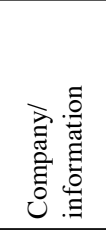 & 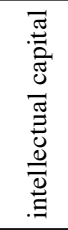 & 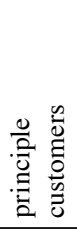 & 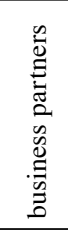 & 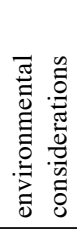 & $\begin{array}{l}\text { a } \\
\frac{\Xi}{2} \\
0 \\
\Xi \\
\Xi \\
\Xi\end{array}$ & 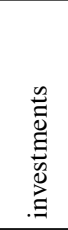 & 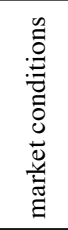 & 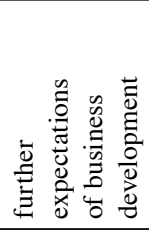 & 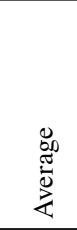 & $\stackrel{0}{\circ}$ \\
\hline 1 & 1 & 1 & 1 & 1 & 1 & 1 & 1 & 1 & $100 \%$ & 1 \\
\hline 2 & 0 & 0 & 0 & 1 & 1 & 0 & 1 & 0 & $38 \%$ & 0 \\
\hline 3 & 1 & 0 & 1 & 1 & 1 & 1 & 1 & 1 & $88 \%$ & 1 \\
\hline 4 & 1 & 1 & 0 & 1 & 1 & 1 & 1 & 1 & $88 \%$ & 1 \\
\hline 5 & 1 & 1 & 0 & 1 & 1 & 1 & 1 & 1 & $88 \%$ & 1 \\
\hline 6 & 0 & 0 & 0 & 0 & 1 & 1 & 0 & 1 & $38 \%$ & 0 \\
\hline 7 & 0 & 0 & 1 & 0 & 0 & 1 & 0 & 1 & $38 \%$ & 0 \\
\hline 8 & 1 & 1 & 1 & 0 & 1 & 0 & 0 & 0 & $50 \%$ & 1 \\
\hline 9 & 1 & 1 & 1 & 0 & 1 & 1 & 0 & 0 & $63 \%$ & 1 \\
\hline 10 & 0 & 0 & 0 & 0 & 1 & 0 & 1 & 1 & $38 \%$ & 0 \\
\hline 11 & 1 & 1 & 1 & 1 & 1 & 1 & 1 & 1 & $100 \%$ & 1 \\
\hline 12 & 0 & 0 & 0 & 1 & 1 & 1 & 1 & 1 & $63 \%$ & 1 \\
\hline 13 & 1 & 0 & 1 & 1 & 1 & 1 & 1 & 1 & $88 \%$ & 1 \\
\hline 14 & 0 & 0 & 0 & 0 & 1 & 1 & 1 & 1 & $50 \%$ & 0 \\
\hline 15 & 0 & 0 & 0 & 0 & 1 & 1 & 1 & 0 & $38 \%$ & 0 \\
\hline 16 & 1 & 0 & 1 & 1 & 1 & 1 & 1 & 1 & $88 \%$ & 1 \\
\hline 17 & 0 & 0 & 1 & 0 & 1 & 0 & 0 & 1 & $38 \%$ & 0 \\
\hline 18 & 0 & 0 & 1 & 0 & 1 & 0 & 0 & 1 & $38 \%$ & 0 \\
\hline 19 & 0 & 0 & 1 & 0 & 1 & 0 & 0 & 0 & $25 \%$ & 0 \\
\hline 20 & 1 & 0 & 1 & 1 & 1 & 1 & 1 & 1 & $88 \%$ & 1 \\
\hline Average & $50 \%$ & $30 \%$ & $60 \%$ & $50 \%$ & $95 \%$ & $70 \%$ & $65 \%$ & $75 \%$ & & \\
\hline Mod & 1 & 0 & 1 & 1 & 1 & 1 & 1 & 1 & & \\
\hline
\end{tabular}

Source: created by the authors

During the research, it was also noted that the minimum number of pages of the annual reports was 6 while the maximum number was 272 pages. The company that presents non-financial information according to the GRI guidelines has the maximum number of pages of the annual report and perhaps it seems less concise but it consists of numerous tables, graphs, charts and images that makes it visually attractive and easier to read and find specific information you need. 
According to the research results, it can be concluded that Croatian companies still do not fully recognize the benefits of integrated reporting. The fact is that only $50 \%$ of investigated companies have disclosed the information about human capital and environmental considerations. Considering that the sample includes twenty companies with the highest revenue in 2016 it is questionable how other, especially smaller companies report on non-financial information. Previous researches have also found that companies use templates from previous years for preparing reports, changing only financial information. Besides, small enterprises frequently disclose positions that have no value as well as accounting policies that have no impact on their business. Possible reason why Croatian companies have not disclosed relevant non-financial information proposed in the framework is that they were not obliged to disclose it since in 2016 the publication of non-financial report was exclusively on a voluntary basis. Today Croatian Accounting Law prescribes the obligation to compile a non-financial report for large public interest entities whose number of employees exceeds 500. Accordingly, it can be concluded that companies in Croatia should make much more effort in the preparation of financial statements and disclosure of relevant financial and non-financial information in order to use the advantages that integrated reporting provides.

\section{Conclusion}

Business reporting enables greater visibility for everyone, those who work within the company and especially those who are not familiar with daily operations of company, company's potential investors, creditors and other stakeholders. While reporting on financial position and business performance through financial statements is a common rule, companies need to focus increasingly on disclosing information of non-financial nature in order to provide a complete picture on long-term value creation. The international accounting organizations have been conducting numerous researches regarding disclosures in the financial statements. Based on the projects, they have been trying to find the cause of an inappropriate reporting framework and propose suggestions for better communication through the disclosure of relevant and entity specific information. Companies should take into account the principle of materiality and preparers should use professional judgement when deciding what information to disclose. They should also bear in mind that investors will probably not look for relevant information in a multitude of irrelevant information. Therefore, it is valuable for companies to draw up integrated report that need to be concise, trustworthy, consistent, and based on the relevant financial and non-financial information.

Research results indicate that integrated reports can provide many benefits for both external and internal users. Reporting financial and non-financial information leads to a greater transparency resulting in stronger stakeholders' confidence and 
better reputation. On the other hand, integrated information can help managers in better understanding business risks and market challenges the company faces with. In order to explore current state of integrated reporting in Croatia, the analysis of available non-financial information in annual reports and notes to the financial statements of largest Croatian companies has been conducted. According to the results of the empirical research, it can be concluded that Croatian companies still do not fully recognize the benefits of integrated reporting. Therefore, there is a time ahead for us to promote the advantages of integrated reporting in order to create value for different stakeholders as a basic prerequisite for successful business performance over the short, medium and long-term.

\section{ENDNOTES}

1 Such as the United Nations (UN) Global Compact, the Guiding Principles on Business and Human Rights implementing the UN 'Protect, Respect and Remedy' Framework, the Organisation for Economic Co-operation and Development (OECD) Guidelines for Multinational Enterprises, the International Organisation for Standardisations ISO 26000, the International Labour Organisation's Tripartite Declaration of principles concerning multinational enterprises and social policy, the Global Reporting Initiative, or other recognised international frameworks (Directive 2014/95/EU).

\section{REFERENCES}

Association of International Certified Professional Accountants, International Integrated Reporting Council \& Black Sun. (2018). Purpose Beyond Profit: The Value of Value - Board-level Insights. Retrieved March 1, 2018, from http://integratedreporting.org/wp-content/uploads/2018/02/Profit_Purpose.pdf

Attolini, G., Pozzoli, M. (2014, December). Is Integrated Reporting Suitable for SMEs. Retrieved March 1, 2018, from https://www.ifac.org/global-knowledge-gateway/business-reporting/discussion/integrated-reporting-suitable-smes

Black Sun \& International Integrated Reporting Council. (2014). Realizing the benefits: The impact of Integrated Reporting. Retrieved March 1, from http://integratedreporting.org/wp-content/ uploads/2014/09/IIRC.Black_.Sun_.Research.IR_.Impact.Single.pages.18.9.14.pdf

Dečman, N. (2016). The use of non-accounting information in the management of a company - Croatian experiences. In 8th International Conference - "An enterprise Odyssey: Saving the Sinking Ship Through Human Capital”, 8-11 June 2016 (pp. 533-540). Zagreb, Croatia: Faculty of Economics \& Business.

European Commission. (2017). Communication from the Commission - Guidelines on non-financial reporting (2017/C 215/01). Retrieved March 1, 2018, from http://eur-lex.europa.eu/legal-content/EN/TXT/PDF/?uri=CELEX:52017XC0705(01)\&from=EN

European Parliament \& Council. (2014). Directive 2014/95/EU of the European Parliament and of the Council of 22 October 2014 amending Directive 2013/34/EU as regards disclosure of non-financial and diversity information by certain large undertakings and groups. Official Journal of the European Union. Retrieved March 1, 2018, from http://eur-lex.europa.eu/legal-content/EN/TXT/PDF/?uri=CELEX:32014L0095\&from=EN 
Galant, A. \& Černe, K. (2017). Non-Financial Reporting in Croatia: Current Trends Analysis and Future Perspectives. Management. 12(1), 41-58. DOI: 10.26493/1854-4231.12.41-58

Global Reporting Initiative. Retrieved March 1, 2018, from https://www.globalreporting.org/information/about-gri/Pages/default.aspx

Global Sustainability Standards Board. (2016). GRI 101 - Foundation. Amsterdam. Retrieved March 1, 2018, from https://www.globalreporting.org/standards/gri-standards-download-center/?g=dff3b3e2-ed2a-4b14-b8e2-a32247f35a68

Institute for Corporate Social Responsibility. Retrieved March 1, 2018, from http://www.idop.hr/hr/ izvjestavanje/izvjestavanje/integrirano-izvjestavanje/prednosti-integriranog-izvjestavanja/

International Integrated Reporting Council (IIRC). Retrieved March 1, 2018, from https://integratedreporting.org/the-iirc-2/

International Integrated Reporting Council. (2013). The International Integrated Reporting Framework. Retrieved March 1, 2018, from http://integratedreporting.org/wp-content/uploads/2013/12/13-12-08-THE-INTERNATIONAL-IR-FRAMEWORK-2-1.pdf

James, M. L. (2015). Accounting majors' perceptions of the advantages and disadvantages of sustainability and integrated reporting. Journal of Legal, Ethical and Regulatory Issues. 18(2), 107-123.

James, M. L. (2012). Sustainability and integrated reporting - opportunities for small and midsize entities. Proceedings of the Academy of Entrepreneurship. 18(2), 15-19.

Kassai J.R. \& Carvalho N. (2016). Integrated Reporting: When, Why and How Did It Happen? In: Mio C. (Eds), Integrated Reporting - a new accounting disclosure. London: Palgrave Macmillan.

KPMG. (2017). The road ahead - The KPMG Survey of Corporate Responsibility Reporting 2017. Retrieved March 1, 2018, from https://assets.kpmg.com/content/dam/kpmg/be/pdf/2017/kpmg-survey-of-corporate-responsibility-reporting-2017.pdf

PwC. (2015). Implementing Integrated Reporting - PwC's pracitical Guide for a new business language. Retrieved March 1, 2018, from https://www.pwc.com/gx/en/audit-services/publications/assets/pwc-ir-practical-guide.pdf

Vitezić, N. \& Petrlić, A. (2018). Integrated Reporting - Concept and Impact on performance of Croatian Companies. Journal of Accounting and Management. 8(1), 71-82. 